\title{
IDENTIFYING SELECTED BEHAVIORAL DETERMINANTS OF RISK AND UNCERTAINTY ON THE REAL ESTATE MARKET
}

\author{
Justyna Brzezicka, M.Sc. \\ Faculty of Geodesy and Land Management \\ University of Warmia and Mazury in Olsztyn \\ e-mail: justyna.brzezicka@uwm.edu.pl
}

\author{
Radoslaw Wisniewski, assoc. prof., PhD \\ Faculty of Geodesy and Land Management \\ University of Warmia and Mazury in Olsztyn \\ e-mail:danrad@uwm.edu.pl
}

\begin{abstract}
Various market behaviors can be characterized as risky or uncertain, thus their observation is important to the real estate market system. The extensive use of behavioral factors facilitates their implementation and studies in relation to the real estate market system. The behavioral approach has established its own instrumentation which enables elements of risk and uncertainty to be quantified.

The belief that behavioral determinants connected with risk and uncertainty occur in the real estate market system (REMS) is the research hypothesis of the present paper which aims to:

1) analyze risk and uncertainty in the REM system using the behavioral approach,

2) identify and systematize behavioral determinants of risk and uncertainly shaping the REM,

3) develop a methodology for measuring behavioral determinants of risk and uncertainty in the REM,

4) present the significance of behavioral determinants of risk and uncertainty on the example of the Olsztyn REM.

The aims were realized by means of a laboratory experiment conducted on a representative sample, as well as through the statistical verification of the obtained results. The article builds on current knowledge regarding the mechanisms of how the REM operates by introducing new issues connected with the behavioral approach to the topic of risk and uncertainty.
\end{abstract}

Keywords: behavioral economics, real estate market, risk, uncertainty, risk aversion, uncertainty aversion.

JEL Classification: D03, D81, R39.

Citation: Brzezicka J., Wisniewski R., 2014, Identyfikacja wybranych behawioralnych determinant ryzyka $i$ niepewności na rynku nieruchomości, Real Estate Management and Valuation, vol. 22, no. 2, s. 30-40.

DOI: $10.2478 /$ remav-2014-0015

\section{Introduction}

In recent years, the behavioral approach has gained much importance in scientific research on the REM (BRZEZICKA 2013; BRZEZICKA, WIŚNIEWSKI 2012, 2013a, 2013b). The in-depth analysis of real estate market participants' behaviors, as well as the observation of the causes leading to them, enable a more thorough explanation of the states of the market and the mechanisms of how it operates. At the same time, there has been increasing interest in the topics of risk (e.g. BEŁEJ, CELLMER 2006; CZAJA 2006; KUCHARSKA-STASIAK 2006a; SIEMIŃSKA 2007, 2013; WOLSKI, ZAŁĘCZNA 2007; ZIĘBA 2006) and uncertainty (KUCHARSKA-STASIAK 2005, 2008, 2013; KUCHARSKA-STASIAK et al. 2009, p. 81 and onwards; 
RADZEWICZ et al. 2011; RADZEWICZ, WIŚNIEWSKI 2011; WIŚNIEWSKI 2007, p. 35 and onwards), which are an immanent characteristic of real estate. The specifics of the real estate market, dynamics of the observed market processes, and complexity of conditions influencing the subjects' decisions allow us to conclude that the random factor plays a significant role in the real estate market system (REMS).

Further parts of the article concern issues connected with risk and uncertainty analyzed in the light of research carried out within the behavioral approach. Following both of the above-mentioned directions of research allows us to draw conclusions regarding the topicality and importance of the conducted analyses.

\section{Risk and uncertainty in the behavioral approach}

The study of the subjects' behaviors and reasons behind them, as well as the analysis of the decisionmaking process observed through a prism of the psychological determinants of making economic decisions are the focal point and field of interest of the behavioral approach (CAMERER, LOEWENSTEIN 2004; KATONA 1980; THALER, SUNSTEIN 2012). This leads to a series of implications which are also reflected in studies connected with risk and uncertainty. It is thus necessary to provide a brief description of the area of research that behavioral science encompasses as far as the analysis of risk and uncertainty is concerned and, for the purposes of the present work, relate them to the sphere and specifics of the real estate market.

Firstly, defining risk and uncertainty in the behavioral approach coincides with scientific literature on the topic, and is in line with generally accepted tendencies. The decisions of subjects can be divided into:

1) deterministic - made under conditions of certainty,

2) probabilistic - made under conditions of risk - the effects of the analyzed actions are uncertain, however uncertainty is not complete, and,

3) assumed under conditions of uncertainty - their effects are completely unpredictable (TYSZKA 2010, p. 25).

Risky choices are characterized by the fact that the actions between which a choice is to be made can lead to various consequences, the probability of which can be determined; the same cannot be said of uncertain choices - probability cannot be determined (TYSZKA, ZALEŚKIEWICZ 2001, p. 56-57). Uncertainty, according to the behavioral definition proposed by TVERSKY and KAHNEMANA (1974, p. 1124), is the probability of the occurrence of an event as well as the conviction that it will or will not happen, expressed by suggestions regarding the future and its subjective assessment. According to this definition, uncertainty ought to be examined not only as regards to the objects but also the subjects. The behavioral approach assumes that uncertainty is not a domain of objects on the REM, but also of the subjects and the surroundings in which these objects and subjects function. Therefore, uncertainly expressed in this way seems to be more complete, as a result of which the processes by which it is identified and analyzed are even more complicated.

The behavioral approach is a subject-based approach - the scope of studies pertains to the subjects' behaviors. When viewed in such a way, the subject becomes the creator of risk and uncertainty, as well as their receiver. Economic decisions are as uncertain and risky as the uncertainty and risk of the conditions by which they are determined. One can say that the behaviors of subjects become an interpretation of the random factor occurring on the market. That is why the behavioral approach analyzes risk to a lesser degree in terms of investments, which are extensively analyzed by researchers favoring the traditional (object) REM approach (e.g. BEŁEJ, CELLMER 2006; BYRBE 1996; CZAJA 2006; KUCHARSKA-STASIAK 2006; SIEMIŃSKA 2007, 2013; WOLSKI, ZAŁĘCZNA 2007; ZIĘBA 2006) and uncertainty not so much in the economic aspect (e.g. KUCHARSKA-STASIAK 2005, 2008; 2013), but instead analyzes these factors through a prism of the psychology of choice. The changeability of the human nature, as well as heuristics and biases (KAHNEMAN 2012; TYSZKA 1999) are of importance here. Their observation in the aggregated approach allows for the real estate market system to be studied holistically.

The behavioral approach has formulated its own viewpoint on choices made under conditions of risk and uncertainty. The classical theory of decisions under conditions of risk assumes that solutions whose expected value (rationality of choice) is the highest should be chosen. The behavioral approach assumes straying from the theory of expected value proposed by Pascal in the XVII century, and next the expected utility hypothesis proposed by BERNOULLI (1738/1954). Since 1944, this theory has 
become a formal model of decision-making under conditions of risk, as it set out the guidelines of rational behavior. A further modification pertained to extending the utility hypothesis to the theory of subjective utility (RAMSEY 1931; DE FINETTI 1937/1980; SAVAGE 1954). In reality, the theory pertains to choices in a state of uncertainty - according to this model, the decision-maker chooses from alternatives that depend on the occurrence of one among many states of nature that contradict one another. In this approach, it is not possible to analyze uncertainty in a statistical (quantitative) paradigm. Introducing the subject element provides grounds for the claim that statistical analyses ought to be supported with system analysis, which calls for treating phenomena as interdependent and incomprehensible until synergic phenomena have been accounted for.

Achievements in behavioral economics came as a breakthrough in studies on the theory of choices under conditions of risk and uncertainty. KAHNEMAN \& TVERSKY designed an alternative model of decision-making - the so-called theory of perspective (KAHNEMAN, TVERSKY 1979, 1992), which gave rise to a new descriptive theory of decisions. Since then, the behavioral approach has made significant achievements in terms of risky and uncertain choices, creating its own instrumentation for their identification and measurement, as well as identifying many behavioral effects pertaining to risk and uncertainty where both gains and losses are concerned. These effects are largely based on the tendency of subjects to give in to temptations (irrational choices), and the divergence from the belief that economical behaviors are fully rational (see SIMON 1955). Decision-makers do not always act in a way that maximizes gains in the economic sense (they may maximize risk of another nature, one of the components of which is economic risk), and their decisions are also varied and dependent on behavioral factors. These factors find wide application in scientific studies, which is why later parts of this work will attempt to relate selected effects to the specifics of the real estate market.

\section{Identification and systematization of behavioral determinants of risk and uncertainty shaping the real estate market}

Among behavioral factors connected with risk and uncertainty, special attention should be drawn to the phenomenon of risk aversion and the phenomenon of uncertainty aversion, as well as their possible significance in the REMS.

Risk aversion, that is a negative attitude towards risk, is defined as reluctance to variants which involve risk. On the opposite end of the spectrum is risk seeking - that is searching for risky variants (ZALEŚKIEWICZ 2011, p. 245). Risk aversion is observed when choosing from among two variants those which are certain, or forgoing a portion of possible gains as the "price paid" for certainty (TYSZKA 2010). Risk-seeking, on the other hand, is demonstrated in forgoing participation in a lottery in exchange for an amount higher than the expected value of the lottery A neutral attitude towards risk is referred to as indifference to risk. Indifference implies being guided by the expected value of a payment (KRAWCZYK 2012, p. 127). The expected utility hypothesis assumes an identical attitude towards risk when dealing with both gains and losses, identical preferences for low as well as high probabilities, and money utility as a linear function of probabilities.

Other solutions were suggested by KAHNEMAN and TVERSKY (1979) in the theory of perspective (TP). The work below focuses only on selected implications of the TP, referring to the topic of risk. The most important assumptions are that:

1) Risk aversion is observed more often than risk-seeking, but only when gains are concerned. Risk-seeking predominates when dealing with losses.

2) The money utility function is not formulated at the final levels of wealth, but stems from the availability of resources dependant on the point of reference (below the point of reference there is a loss, above it, a gain); this point can be the current resource or a point indicated in the decision problem.

3) The value function from TP, which corresponds to the utility function, is concave for gains, and convex for losses, and is steeper for the later than the former. This property - referred to as an aversion to loss - leads to assumptions characterized by an asymmetric, S-shaped, value function. According to the function, more value is placed on changes concerning losses and gains of smaller values than changes pertaining to results characterized by higher values. What is more, gains and losses are assessed differently - a loss is more "painful".

4) $\mathrm{TP}$ also introduces the function of decision weights, requiring the decision-maker to use weights, which are not probabilities but a transformation of these probabilities. Decision weight expresses the amount of consideration a given option receives (DOMURAT 2008, p. 14). 
5) There are two phases to making decisions under conditions of risk (the editing phase and the assessment phase); first, an initial analysis of the problem is performed using decision heuristics, and next the subjective values of the individual variants are determined and one of them is chosen (ZALEŚKIEWICZ 2011, p. 104).

TP pertains to choices under conditions of risk, and assessing the attitudes of market participants on the real estate market towards risk constitutes a key aspect of the studies. Studying choices under conditions of uncertainty complements research on choices involving the risk variant. Uncertainty aversion (referred to as ambiguity aversion in literature) (TYSZKA 2010, p. 328-331) is expressed as the reluctance to situations in which uncertainty occurs. The effect of uncertainty aversion can have two grounds:

1) a cognitive nature - uncertainty influences the perception of lowering the chance of a favorable outcome to the event,

2) a motivational nature - people can attribute a lower value to an unclear situation due to the negative lack of information.

The studies prove that uncertainty aversion and risk aversion are weakly correlated with each other, and that they are in fact two separate phenomena. People express a preference to risky behaviors more than to uncertain ones, though in the case of low probabilities occurring in risky variants - they opt for uncertain choices over those that are risky (TYSZKA 2010).

Observations regarding risk and uncertainty according to the behavioral approach are not without influence where the real estate market system is concerned. As noticed earlier, market participants (entering into transactions) are the creators of risk and uncertainty, as well as their receivers. Moreover, when operating in the real estate market system, they also naturally experience and come into contact with risk and uncertainty which occur within, and are generated by the system. This means that their attitudes are influenced by risk and uncertainty, and that their individual approach to these categories is reflected in decisions on entering into transactions. These attitudes become particularly apparent in situations when decisions are to be made. In the case of buying-selling real estate, these attitudes can be expressed among others by:

1) the length of the investment process,

2) searching for an appropriate buyer (see BRUSS 2005),

3) the actual decision regarding the purchase (to buy or not to buy) or sale (to sell or not to sell), do it now or wait longer (to wait or not to wait)?,

4) the issue of choosing the "right" location with the preferred attributes,

5) the means of financing the investment,

6) many other examples.

\section{Empirical results}

The empirical part of the research was realized using a survey. The survey was conducted among a group of 176 students attending the University of Warmia and Mazury in Olsztyn and students of the Off-Campus Teaching Center of the University of Warmia and Mazury in Olsztyn located in Torun, as well as the Old Polish University in Kielce. Six of the surveys were completed incorrectly, thus 170 questionnaires were qualified for further analysis. The subjects of the study were students majoring in land management as well as geodesy and cartography, whose study programs involved gaining information on topics connected with the real estate market. The research was conducted in January of 2014.

\subsection{Aims of the study}

The study aimed to:

1) determine the subject profile of market attitudes regarding decisions characterized by risk and uncertainty,

2) determine an individual's attitude to risk (risk aversion, risk-seeking, indifference to risk) on the example of a lottery involving money, as well as on the example of a lottery involving real estate,

3) determine an individual's attitude to uncertainty (uncertainty aversion, uncertainty-seeking, indifference to uncertainty) on the example of a lottery involving money, as well as on the example of a lottery involving real estate. 
In both cases, the lottery with money served as a reference point. The study mimicked choices dealing with gains as well as losses.

\subsection{Methodology of measuring attitudes towards risk and uncertainty}

The game method using the lottery variant and variant of certainty was applied to measure the attitudes of market participants towards risk (cf. TYSZKA 2010, p. 202; WÄRNERYD 1988). The surveyed students were asked to indicate the variant which they would like to choose. The choice was made between a lottery in which one of two payments could be received with a probability of $p$ and 1-p (Variant A), as well as the expected value of this gamble (Variant B). The respondents decided whether they preferred to receive a certain payment or to take part in the lottery, or if they were indifferent to the variant chosen. A 50\% level of probability $p$ was accepted. The scheme of the survey question has been presented below:

$$
\text { A: receive } \mathrm{X} \mathrm{zl}(50 \%) \text { or } 0 \mathrm{zl}(50 \%) \quad \mathrm{B} \text { : be guaranteed to receive } 1 / 2 \mathrm{X} \mathrm{zl} \text {. }
$$

The study allows for three attitudes towards risk to be determined, i.e. risk aversion, risk-seeking, and a neutral stance to risk. The results ought to be interpreted as follows:

1) a decision-maker choosing A over B signifies risk-seeking (a risk-taker),

2) a decision-maker choosing $B$ over A signifies risk aversion (a hedger),

3) a decision-maker declaring impartiality to A or B signifies indifference, that is a neutral stance to risk.

This method can also be adopted to study the subjects' attitudes towards risk regarding choices dealing with loss. The scheme of the survey question has been presented below:

$$
\text { A: lose } \mathrm{Xzl}(50 \%) \text { or } 0 \mathrm{zl}(50 \%) \text { B: be guaranteed to lose } 1 / 2 \mathrm{X} z l \text {. }
$$

Based on the algorithms presented above, the scheme of the question was adapted to analyze the attitudes of market participants towards uncertainty when dealing with gain as well as loss. Variant A was modified in the question so that its choice would be connected with the toss of a coin. Information was provided that, based on a reliable source of information, the coin used in the lottery is known to be a fake (it is impossible to determine the probability of heads or tails occurring). The scheme of the question has been presented below:

\section{A: TAILS: receive $\mathrm{X} z l$ or HEADS: $0 \mathrm{zl} \quad$ B: be guaranteed to receive $\frac{1 / 2}{2} \mathrm{zl}$.}
A: TAILS: lose $\mathrm{X}$ zl or HEADS: $0 \mathrm{zl}$
B: be guaranteed to lose $1 / 2 \mathrm{X}$ zl.

Although the study method enables us to accept unified criteria of qualifying the subjects into one of the groups of attitudes towards risk or uncertainty, it is not free of flaws. Such a study is imperfect, due to the fact that the results are prone the effect of certainty, that is the preference of the guaranteed variant (see KAHNEMAN, TVERSKY 1979) (the occurrence of the certainty effect has been confirmed in relation to the REM, see BRZEZICKA et al. 2013). The respondents may tend to lean towards certain variants not due to being risk-averse, but rather because of exhibiting a preference for guaranteed outcomes. Other methods for studying attitudes towards risk are also known (e.g. HOLT \& LAURY 2002, methods proposed by WÄRNERYD 1988, or the method of expected loss according to TYSZKI 2004, p. 323), but they are less flexible in terms of studying the attitudes towards risk on the example of real estate. In order to study attitudes towards risk and uncertainty, the variants of choices were modified in such a way that they pertained to real estate. The survey questionnaire and obtained results are discussed in the following section of the article.

\subsection{Survey questionnaire}

The survey questionnaire consisted of two parts:

1) part 1 - pertaining to risk,

2) part 2 - pertaining to uncertainty.

The studies dealt with "small sums" (A: $100 \mathrm{zl}$ or $0 \mathrm{zl}$; B: $50 \mathrm{zl}$ ) as well as "large sums" (A: 10,000 zl or $0 \mathrm{zl} ; \mathrm{B}: 5,000 \mathrm{zl}$ ), both when dealing with gains as well as losses. A variant referring to real estate was introduced in further questions - the amount of 10,000 $\mathrm{zl}$ was changed to the shared ownership of a building plot in a good location. Analogical questions pertaining to real estate when dealing with loss and relating to the aspect of real estate insurance were also accounted for (insure and be guaranteed to lose 5,000 zl, or don't insure and face a probability of losing 10,000 $\mathrm{zl}$ or nothing). The 
questions in the second part of the survey corresponded to the ones in the first part - the modification concerned introducing the element of uncertainty - that is the tossing of a fake coin.

Abbreviations were used to refer to questions in the survey questionnaire in further sections of the article, with their explanation provided below:

1) Part 1 - attitudes towards risk:

P1_1.1 - attitudes towards risk on the example of money dealing with gains - small sums,

P1_1.2 - attitudes towards risk on the example of money dealing with gains - large sums,

P1_2.1 - attitudes towards risk on the example of money dealing with losses - small sums,

P1_2.2 - attitudes towards risk on the example of money dealing with losses - large sums

P1_3 - attitudes towards risk on the example of real estate dealing with gains - large sums,

P1_4 - attitudes towards risk on the example of real estate dealing with losses - large sums,

2) Part 2 - attitudes towards uncertainty:

P2_1.1 - attitudes towards uncertainty on the example of money dealing with gains - small sums,

P2_1.2 - attitudes towards uncertainty on the example of money dealing with gains - large sums,

P2_2.1 - attitudes towards uncertainty on the example of money dealing with gains - small sums,

P2_2.2 - attitudes towards uncertainty on the example of money dealing with gains - large sums,

P2_3 - attitudes towards uncertainty on the example of real estate dealing with gains - large sums,

P2_4 - attitudes towards uncertainty on the example of money dealing with losses - large sums.

Figure 1 presents the outline of the questions and aim of the study based on part 1 of the survey (the study of attitudes towards risk).

\begin{tabular}{|c|c|}
\hline $\begin{array}{c}\text { Part 1_1 } \\
\text { study on the example of money } \\
\text { dealing with gain } \\
\text { determining market participants' profile of } \\
\text { attitudes towards risky decisions (risk } \\
\text { aversion, risk-seeking, indifference to risk) } \\
\text { Question 1 - small sum (P1_1.1) } \\
\text { Question 2 - large sum (P1_1.2) }\end{array}$ & $\begin{array}{c}\text { Part 1_2 } \\
\text { study on the example of money } \\
\text { dealing with loss } \\
\text { determining market participants' profile of } \\
\text { attitudes towards risky decisions (risk } \\
\text { aversion, risk-seeking, indifference to risk) } \\
\text { Question 1 - small sum (P1_2.1) } \\
\text { Question 2 - large sum (P1_2.2) }\end{array}$ \\
\hline $\begin{array}{c}\text { Part 1_3 } \\
\text { study on the example of real estate } \\
\text { dealing with gain } \\
\text { determining market participants' profile of } \\
\text { attitudes towards risky decisions (risk } \\
\text { aversion, risk-seeking, indifference to risk) } \\
\text { Question 1 - co-ownership of a plot of land }\end{array}$ & $\begin{array}{c}\text { Part 1_4 } \\
\text { study on the example of real estate } \\
\text { dealing with loss } \\
\text { determining market participants' profile of } \\
\text { attitudes towards risky decisions (risk } \\
\text { aversion, risk-seeking, indifference to risk) } \\
\text { Question 1 - insuring an apartment }\end{array}$ \\
\hline
\end{tabular}

Fig. 1. Outline of Part 1 of the questionnaire - the study of attitudes towards risk. Source: authors' own.

\subsection{Study results}

1. Risk-seeking was confirmed for small sums (55\% of responses), whereas risk aversion characterized higher ones (81\% of responses) (see fig. 2 and 3 ). 


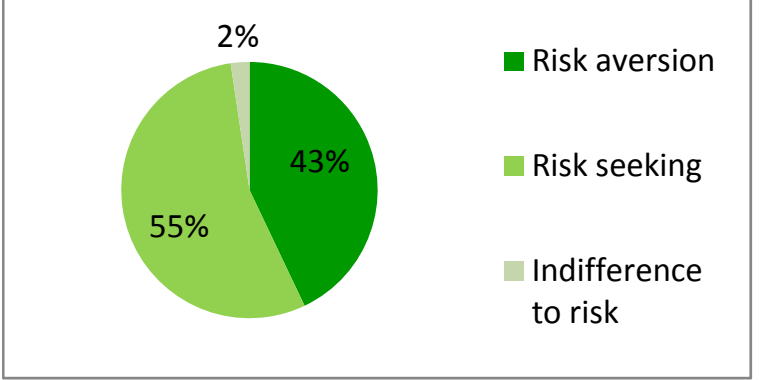

Fig. 2. Question P1_1.1. Source: own study.

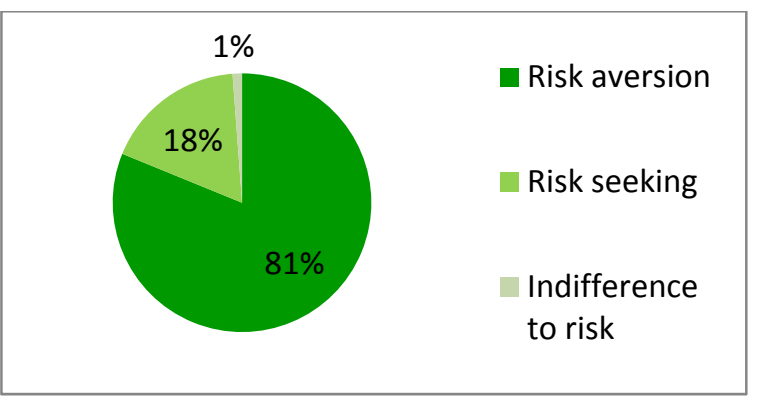

Fig. 3. Question P1_1.2. Source: own study.

2. Risk seeking for small sums $(67 \%)$ as well as risk tendency for higher sums $(67 \%)$ were confirmed when dealing with losses (see fig. 4 and 5).

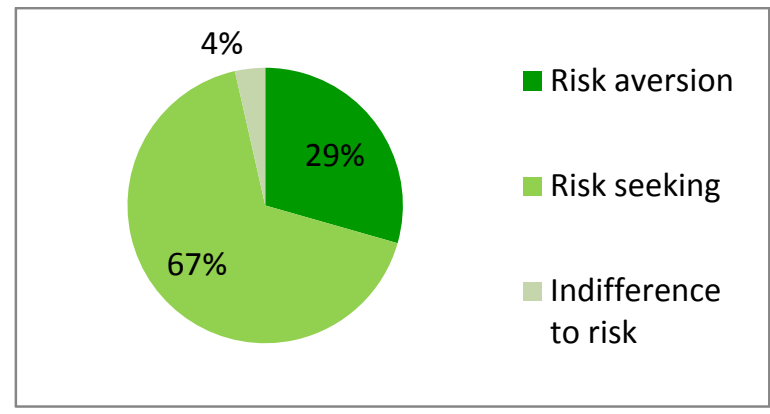

Fig. 4. Question P1_2.1. Source: own study.

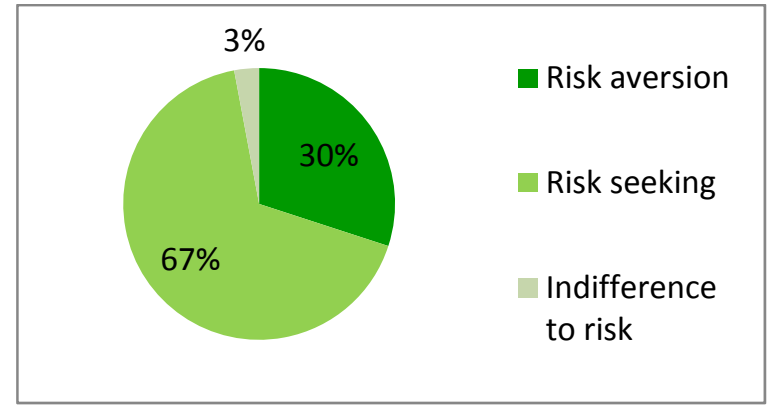

Fig. 5. Question P1_2.2. Source: own study.

Conclusions: The responses of the people surveyed confirmed the assumptions of the theory of perspective. The respondents were found to be risk-seeking where small sums of money were concerned, but risk averse when dealing with large sums (fear of losing greater amounts of money). The aversion was clearly evident - 4 out of 5 respondents exhibited such an aversion. On the other hand, in the case of risky decisions dealing with loss, the respondents were risk-seeking in terms of both small as well as large sums - their preferences revealed a willingness to assume risk when given a $50 \%$ chance of avoiding losses. Moreover, the amount of money at stake does not seem to make a difference - the percentage of responses expressing risk-seeking tendency was found to be $67 \%$ for small as well as large sums, with studies not revealing Pearson's simple correlation between answers. 3. Uncertainty aversion for small sums (57\%) as well as uncertainty aversion for larger amounts of money $(79 \%)$ were confirmed when dealing with gains (see figures 6 and 7).

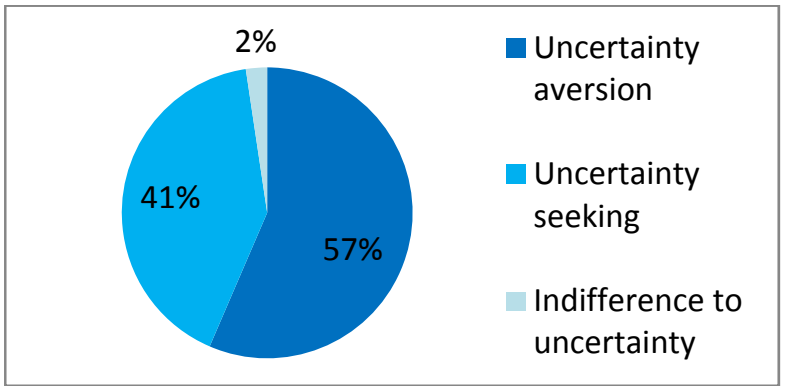

Fig. 6. Question P2_1.1. Source: own study.

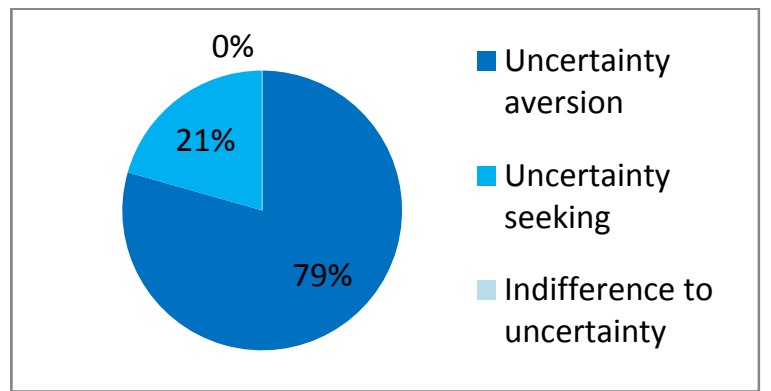

Fig. 7. Question P2_1.2. Source: own study.

4. Uncertainty-seeking for small sums $(52 \%)$ as well as uncertainty-seeking for larger amounts of money (53\%) were confirmed when dealing with losses (see figures 8 and 9). 


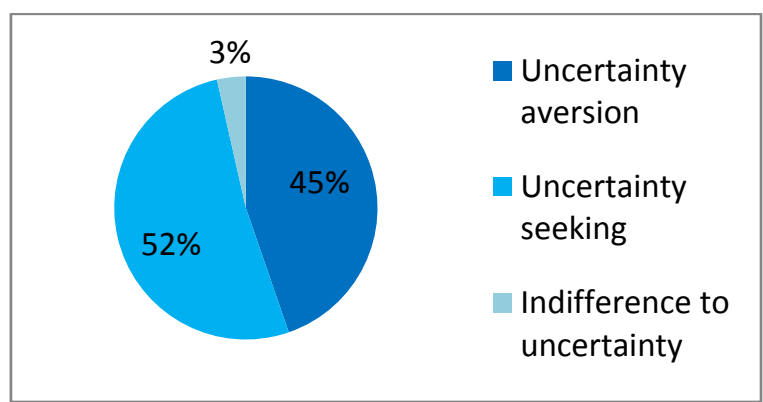

Fig. 8. Question P2_2.1. Source: own study.

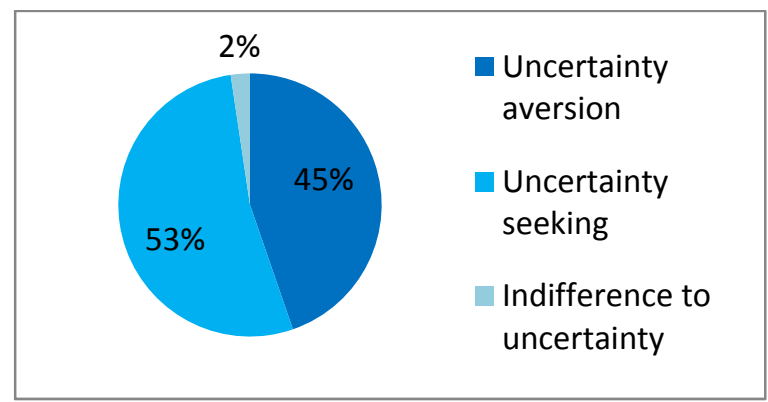

Fig. 9. Question P2_2.2. Source: own study.

Conclusions: in the case of questions regarding uncertain decisions when dealing with gains the respondents were found to be uncertainty averse for small as well as large sums of money), whereas uncertainty-seeking behavior prevailed when the questions concerned losses - (for small as well as large sums). The answers clearly indicate an unwillingness to suffer a loss, further strengthened by the element of uncertainty. Moreover, people tend to be more risk averse when larger amounts of money are at stake. Also in the case of uncertainly, similarly to questions concerning risk, the amount of money appears to be without influence when dealing with losses - the results remain at a comparable level (slightly over $50 \%$ of the responses). When comparing the respondents' answers to questions concerning uncertain decisions to those referring to risky ones, the uncertain element decreased the tendency to take part in the drawing (a lack of information) - the tendency was found to be $67 \%$ in the case of risk and approximately $50 \%$ for uncertainty. The study confirms the findings presented in literature (e.g. TYSZKA 2010) on the greater preference of risky than uncertain decisions.

5. Risk aversion (54\%) as well as uncertainty aversion (70\%) were confirmed in the case of questions concerning real estate when dealing with gains (see figures 10 and 11).

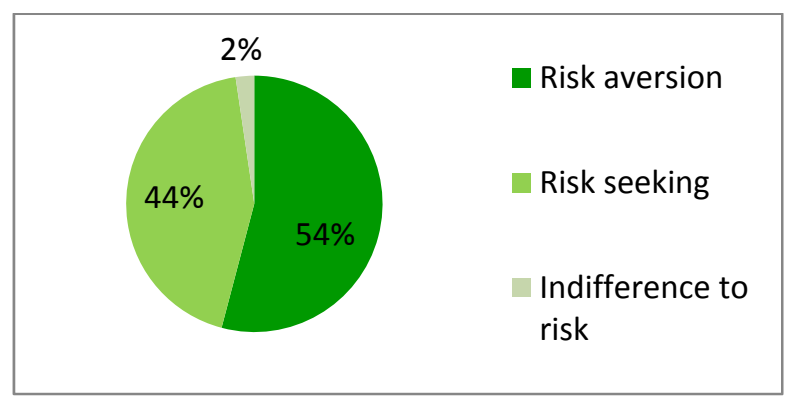

Fig. 10. Question P1_3. Source: own study.

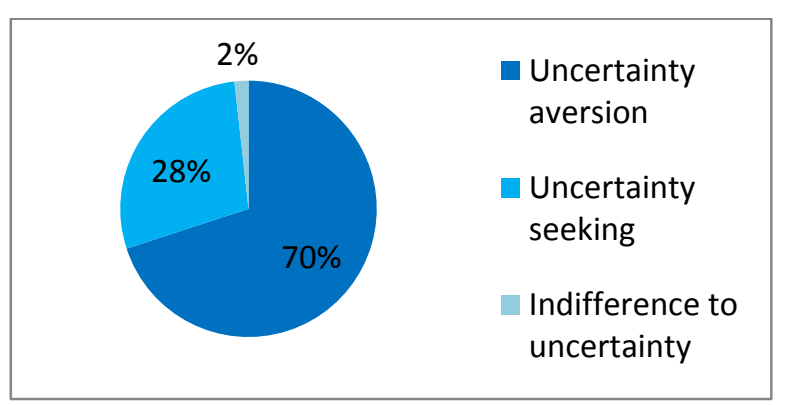

Fig. 11. Question P2_3. Source: own study.

6. Risk aversion (55\%) as well as uncertainty aversion (64\%) were confirmed in the case of questions concerning real estate when dealing with losses (see figures 12 and 13).

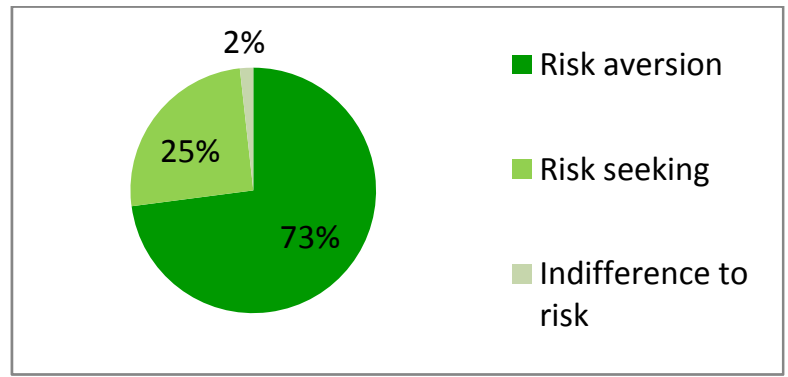

Fig. 12. Question P1_4. Source: own study.

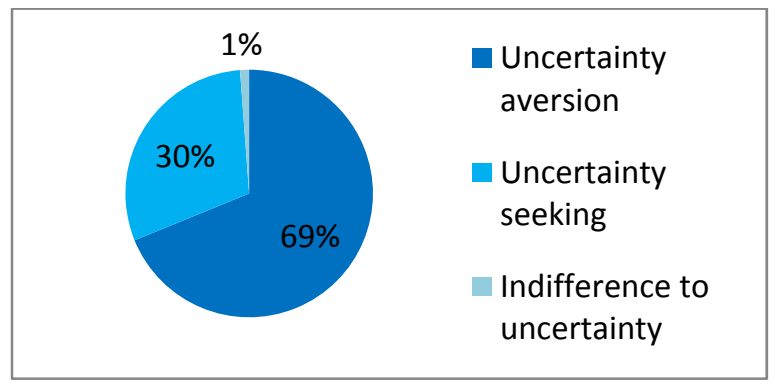

Fig. 13. Question P2_4. Source: own study.

Conclusions: in the case of questions regarding real estate, the respondents were in agreement as to indicating risk aversion, as well as uncertainty aversion, when dealing with both gains and losses. As regards to gains, the majority of people would prefer to get 5,000 $\mathrm{zl}$ than engage in a lottery for the coownership of a plot of land. Co-ownership is not "a strong enough lure" to convince decision-makers 
to take their chances and play the game. Risk and uncertainty aversion and in the case of losses, however, allows us to discover an inconstant preference of the surveyed students - in the case of questions pertaining to sums of money (questions for large sums) - the study subjects were found to be risk- and uncertainty-seeking when dealing with losses, which was not the case when real estate was at stake. These behaviors are different than one would assume based on the theory of perspective, according to which in reference to loss, subjects tend to be risk-seeking. This question pertained to the issue of insuring real estate (insure and lose 5,000 $\mathrm{zl}$ or don't insure with a 50\% probability of losing twice as much). This observation is an important characteristic of the real estate market and can be interpreted in three different ways.

Firstly, the decision-makers exhibit an inconstant preference, which is in accordance with the assumptions of the behavioral approach. The behavioral approach emphasizes the complexity of the motives that subjects are guided by. The inconstancy of preferences is also typical for the real man model (see BRZEZICKA, WIŚNIEWSKI 2014), rather than the economic man (homo economicus) one used in mainstream economics. The tendency to change preferences, as a behavioral feature of subjects, can cause lead to many heuristics and biases, and in consequence result in abnormal states of the real estate market. Based on these premises, if people wish to be consequential, they should be risk- and uncertainty-seeking when dealing with loss on the example of real estate! The answers, however, indicate risk aversion and uncertainty aversion. This implies a divergence from the expected utility hypothesis due to not fulfilling the axiom of transitivity (otherwise referred to as the axiom of consent preference), which would confirm the lack of rationality. Rationality in the theory of mainstream economics is indicated by compatibility with the expected utility hypothesis.

Secondly, the decision-makers perceive real estate as being more valuable than the amount of money equivalent to the price of the real estate, and this is why they do not want to lose it. Real estate is a value in itself. The study reveals the "luxurious" nature of real estate, as a rare and desirable good in the eyes of market participants. The study has a practical nature and can serve as a starting point for further research on how prices and values are perceived on the real estate market by its participants.

Thirdly, decision-makers succumbed to the endowment effect (see KAHNEMAN et al. 1991). According to TYSZKI (2010, p. 271), the endowment effect is expressed by the reluctance to give up something we already possess. We expect to get more in return for goods which are in our possession than we would be willing to offer for them when we are just considering acquiring them. The decision-makers were willing to choose the variant which would result in a definite loss in order not risk a $50 \%$ probability of losing twice as much. This question was formulated differently than the previous ones: "Imagine that you are in possession of an apartment and are considering having it insured ...". The question implies that the real estate, which becomes the object the decision revolves around, is in the decision-maker's possession. The study allows us to draw the conclusion that decision-makers do not want to lose something that is already theirs - a loss of 10,000 $\mathrm{zl}$ in this situation is "more painful" than losing 10,000 $\mathrm{zl}$ which are not yet in the decision maker's possession.

\section{Summary and conclusions}

The conducted study allows us to witness the importance of the behavioral approach as well as the validity of its research concerning the real estate market system. As noticed earlier, the subjects operating in the real estate market system are the creators of risk and uncertainty, as well as the receivers. The individual decisions made by the subjects, affected by risk and uncertainty, are carried over to the real estate market system where they function on an aggregated level leading to systematic mistakes. The study indicates the necessity to include the subject element in research focused on real estate market risk and uncertainty, as it complements traditional ("object") studies on investment risk and uncertainty as an immanent feature of the real estate market. The study indicates the presence of "bundles" of risk- and uncertainty-inducing factors derived from the subject side of the equation. Upon having occurred, these elements function in the REMS and can lead to changes in the system, observable on various market planes.

The research carried out for purposes of this article reveals the potential of the subject side of the real estate market as well as the dangers which arise from it, but due to its laboratory nature may entail certain limitations. While laboratory conditions safeguarded the decisions of those surveyed, decisions made under actual market conditions do not have to reflect the declared preferences and tendencies toward risk and uncertainty expressed in the survey study. When studying the attitudes 
and tendencies of decisions-makers, it is unwarranted to draw conclusions regarding the states of the market without carrying out an in-depth qualitative-quantitative analysis.

The authors also wish to highlight the practical nature of the studies, as they believe that the topic at hand calls for an in-depth analysis, which they intend to carry out in follow-up studies. In the light of the present research, a new category of science concerning the creation of risk and uncertainty by real estate market participants emerges, necessitating further observations.

\section{References}

BEŁEJ M., CELlMER R., 2006, Koncepcja oceny poziomów ryzyka na rynku nieruchomości i sposobów jego uwzgledniania w procesie inwestycyjnym (Concept of assessing levels of risk on the real estate market and means of accounting for it in the investment process), Studia i Materiały Towarzystwa Naukowego Nieruchomości, no. 14 (1), pp. 13-26.

BERNOULLI D., 1738/1954, Exposition of a new theory on the measurement of risk, translated by Louise Sommer, Econometrica (pre-1986), no. 22, pp. 23-36.

BRUSS F. T., 2005., Jak przechytrzyć niepewność (How to fool uncertainty), Decyzje, no. 4, pp. 61-70.

BRZEZICKA J., WIŚNIEWSKI R., 2012, Behawioralne aspekty rynku nieruchomości (Behavioral aspects of the real estate market), Studia i Materiały Towarzystwa Naukowego Nieruchomości, no. 20 (2), pp. 21-31.

BRZEZICKA J., 2013, Sezonowość rynku nieruchomości (The seasonal character of real estate market), Świat nieruchomości, no. 84, pp. 26-31.

BRZEZICKA J., WIŚNIEWSKI R., 2013a, Ekonomia behawioralna a rynek nieruchomości - teoria $i$ praktyka (Behavioral economics and real estate market - theory and empiricism), Psychologia ekonomiczna, no. 3, pp. 6-18.

BRZEZICKA J., WiŚNIEWSKI R., 2013b, Calendar Effects on the Real Estate Market, Real Estate Management and Valuation, no. 21 (2), pp. 13-21.

BRZEZICKA J., WIŚNIEWSKI R., 2014, Homo oeconomicus and Behavioral Economics, work under review in: Contemporary Economics.

BRZEZICKA J., RADZEWICZ A., KURYJ-WYSOCKA O., WIŚNIEWSKI R., 2013, Badanie efektu pewności i izolacji na rynku nieruchomości w kontekście teorii perspektywy (Certainty and Insulation Effects in the Real Estate Market in the Context of Prospect Theory), Studia ekonomiczne, no. 4, pp. 560-582.

BYRNE P. 1996., Risk, uncertainty and decision-making in property development, E \& FN Spon, London.

CAmerer C. F., Loewenstein G., 2004, Behavioral Economics: Past, Present, Future., (in:) C. F. Camerer, G. Loewenstein, M. Rabin, Advances in Behavioral Economics (pp. 3-59)., Princeton and Oxford: Princeton University Press.

CzAJA J, 2006, Szacowanie wartości nieruchomości dla zabezpieczenia wierzytelności kredytowych (Assessing real estate value for securing mortgages), Studia i Materiały Towarzystwa Naukowego nieruchomości, no. 14 (1), pp. 35-47.

De FinetTi B. 1937/1980, La Prévision: Ses Lois Logiques, Ses Sources Subjectives. Annales de l'Institut Henri Poincaré, 7: 1-68; translated as: Foresight. Its Logical Laws, Its Subjective Sources. in: KYBURG, Jr. H.E. and SMOKLER, H.E. (eds.) Studies in Subjective Probability. New York: Robert E. Krieger Publishing Co.

DOMURAT K, 2008, Rola "subiektywnych" prawdopodobieństw w decyzjach z ryzykiem (Role of "subjective" probabilities in risky decisions), Decyzje, no. 10, pp. 5-26.

FORLICZ S., 2001, Niedoskonała wiedza podmiotów rynkowych (Imperfect knowledge of market participants), PWE, Warszawa.

HEILPERN S., 1998, Dynamika i niepewność w modelowaniu ekonomicznym (Dynamics and uncertainty in economic modeling), Wyd. AE im. Oskara Langego, Wrocław.

Holt CH. A., LAURY S.A., 2002, Risk aversion and incentive effects, American Economic Review, no. 92, pp. 1644-1655.

KAHNEMAN D., 2012, Pułapki myślenia. O myśleniu szybkim i wolnym (Mind traps. On thinking slowly and quickly), Media Rodzina, Poznań.

KAHNEMAN D., TVERSKY A., 1974, Judgement Under Uncertainty: Heuristics and Biases, Science 185 (4157), pp. 1124-1131.

KAHNEMAN D., TVERSKY A., 1979, Prospect theory: An analysis of Decision under risk, Econometrica, vol. 47 (2), pp. 263-292.

KAHNEMAN D., TVERSKY A., 1992, Advances in prospect theory: Cumulative representation of uncertainty, 
Journal of Risk and Uncertainty, no. 5, pp. 297-323.

KAHNEMAn D., KNETSCH J. L., THALER R. H., 1991, Anomalies: The endowment effect, loss aversion, and status quo bias, The journal of economic perspectives, 5(1), 193-206.

KATONA G., 1980, Essays on Behavioral Economics, University of Michigan Press, Ann Arbor, MI.

KRAWCZYK M., 2012, Ekonomia eksperymentalna (Experimental economics), Oficyna a Wolters Kluwer business, Warszawa.

KUCHARSKA-STASIAK E., 2005, Uncertainty of Valuation in the Emerging Markets, The Polish Case. ERES Conference 2005.

KUCHARSKA-STASIAK E., 2006a, Ryzyko inwestowania na rynku nieruchomości (Risk of investing on the real estate market), Studia i Materiały Towarzystwa Naukowego Nieruchomości, no. 14 (1), pp. 107-122.

KUCHARSKA-STASIAK E., 2006b, Nieruchomość w gospodarce rynkowej (Real estate in the market economy), PWN, Warszawa.

KUCHARSKA-STASIAK E., 2008, Uncertainty of Valuation in Expropriation Processes - the Case of Poland, Nordic Journal of Surveying and Real Estate Research, Special Series, vol. 3, pp. 83-92.

KUCHARSKA-STASIAK E., SCHNEIDER B., ZAŁĘCZNA M., 2009, Methodology for local and regional real estate market, Wydawnictwo Uniwersytetu Łódzkiego, Łódź.

KUCHARSKA-STASIAK E., 2013, Uncertainty of property valuation as a subject of academic research, Real Estate Management and Valuation, no. 21(4), pp. 17-25.

RADZEWICZ A., RENIGIER-BIEOZOR M., WIŚNIEWSKI R., 2011, From uncertainty to the efficiency of the real estate market, 18th Annual European Real Estate Society Conference in Eindhoven, the Netherlands.

RADZEWICZ A., WIŚNIEWSKI R. 2011, Niepewność rynku nieruchomości (Uncertainty of the real estate market), Studia i Materiały Towarzystwa Naukowego Nieruchomości, no. 19(1), pp. 47-57.

RAMSEY F.P. 1931, Truth and Probability, w: Ramsey F.P. 1931. The Foundations of Mathematics and other Logical Essays, Chapter VII, pp. 156-198, New York: Harcourt, Brace and Company.

SAVAGE J.L., 1954, The foundations of statistics, John Wiley \& Sons, Inc., New York.

SIEMIŃSKA E., 2007, Globalizacja a system finasowania rynku nieruchomości (Globalization and the system of financing the real estate market), Studia i Materiały Towarzystwa Naukowego Nieruchomości, no. 15 (1-2), p. 95-102.

SIEMIŃSKA E., 2013, Ryzyka inwestowania $i$ finansowania na rynku nieruchomości w kontekście etyki $i$ spotecznej odpowiedzialności (Risks of investing and financing on the real estate market in the context of ethics and social responsibility), Wydawnictwo Naukowe Uniwersytetu Mikołaja Kopernika, Torun.

SIMON A.H., 1955, A behavioral model of rational choice, Quarterly Journal of Economics, no. 69, p. 99-118.

THALER R. H., SUNSTEIN C. R., 2012, Impuls. Jak podejmować wtaściwe decyzje dotyczace zdrowia, dobrobytu $i$ szczęścia (Impulse. How to make the right decisions regarding health, well-being and happiness), Zysk i Ska, Poznań.

TYSZKA T., 1999, Psychologiczne pułapki oceniania i podejmowania decyzji (Psychological traps of assessing and making decisions), Gdańskie Wydawnictwo Ekonomiczne, Gdańsk.

TYSZKA T., 2004, Psychologia ekonomiczna (Economic psychology), Gdańskie Wydawnictwo Psychologiczne, Gdańsk.

TYsZKA T, 2010, Decyzje. Perspektywa psychologiczna i ekonomiczna (Decisions. Psychological and economic perspective), Wyd. Scholar.

TYSZKA T., ZALEŚKIEWICZ T., 2001, Racjonalność decyzji (Rationality of decisions), PWE, Warszawa.

VON NeumAnN J., Morgenstern O., 1944/1990, Theory of games and economic behavior, Princeton University Press, Princeton.

WÄRNERYD K.E., 1988, Risk attitudes and risky behavior, Journal of Economic Psychology, no. 17, p. 749770.

WIŚNIEWSKI R., 2007, Wielowymiarowe prognozowanie wartości nieruchomości (Multidimensional forecasting of real estate value), Wydawnictwo Uniwersytetu Warmińsko-Mazurskiego, Olsztyn.

WOLSKI R., ZAŁĘCZNA M., 2007, Mieszkanie jako alternatywna inwestycja (Housing as an alternative investment), Studia i Materiały Towarzystwa Naukowego Nieruchomości, no. 15 (3-4), pp. 105-119.

ZALEŚKIEWICZ T., 2011, Psychologia ekonomiczna, PWN, Warszawa.

ZIĘBA M., 2006, Identyfikacja i ograniczenie ryzyka w zarzadzaniu nieruchomościami komercyjnymi (Identifying and limiting risk in commercial real estate management), Studia i Materiały Towarzystwa Naukowego Nieruchomości, no. 14 (1), pp. 246-258. 